\title{
Agglomeration and Economic Growth in the Special Region of Yogyakarta (2005-2016)
}

\author{
By: \\ Wahyu Dwi Artaningtyas ${ }^{1)}$, Asih Sri Winarti ${ }^{1)}$, Jamzani Sodik ${ }^{1 *}$ \\ ${ }^{1)}$ Faculty of Economics UPN Veteran Yogyakarta \\ *)Corresponding Author: jamzani.sodik@upnyk.ac.id
}

Submission: 21 January 2019, Accepted: 29 August 2019

\begin{abstract}
This study aims to determine the development and linkages between production agglomeration and population agglomeration to the economic growth in DIY. The approach used is the estimation method of fixed effect panel data regression using DIY city/regency administration data in 2005-2016. The results showed that population agglomeration had a significant positive effect on economic growth, while production agglomeration had no effect on economic growth in model I. Whereas in model II, production, population agglomeration and HDI affected economic growth, labor force negatively affected growth, and unemployment had positive, significant effect on economic growth. Poverty level have a negative effect on economic growth. Cities/regencies that have a positive fixed cross effect on economic growth are Sleman, Gunungkidul, and Kulonprogo Regency, while Yogya City and Bantul Regency show a negative sign.
\end{abstract}

Keywords: Agglomeration, Economic Growth, HDI, Labor Force, Poverty, Unemployment

\begin{abstract}
ABSTRAK
Penelitian ini bertujuan untuk mengetahui perkembangan dan keterkaitan antara aglomerasi produksi dan aglomerasi populasi penduduk terhadap pertumbuhan ekonomi di DIY. Pendekatan yang digunakan adalah metode regresi data panel fixed effect dengan menggunakan data administrasi kota/kabupaten DIY pada tahun 2005-2016. Hasil penelitian menunjukkan aglomerasi populasi penduduk memiliki efek positif signifikan terhadap pertumbuhan ekonomi, sementara aglomerasi populasi penduduk tidak berpengaruh terhadap pertumbuhan ekonomi dalam model I. Sedangkan dalam model II, produksi, aglomerasi penduduk dan HDI dipengaruhi pertumbuhan ekonomi, tenaga kerja terkena dampak negatif pertumbuhan, dan pengangguran berpengaruh positif dan signifikan terhadap pertumbuhan ekonomi. Tingkat kemiskinan berpengaruh negatif terhadap pertumbuhan ekonomi. Kota/kabupaten yang memiliki efek silang tetap positif terhadap pertumbuhan ekonomi adalah Kabupaten Sleman, Gunungkidul, dan Kulonprogo, sedangkan Kota Yogya dan Kabupaten Bantul menunjukkan efek negatif.
\end{abstract}

Kata Kunci : Aglomerasi, Pertumbuhan Ekonomi, Angkatan Kerja, Kemiskinan, Pengangguran 


\section{INTRODUCTION}

City as a spatial embodiment tends to be experiencing changes (physical and non-physical aspects) from time to time. Two main factors play a major role in these changes, namely population factors and policy aspects. Population aspects include broad social conditions, such as political, social, economic, cultural, and technology also always changes from time to time. The quantity and quality of its activities always increase with increasing population and changing values. Thus the space as a container for these activities always undergoes continuous changes (Riyadi, 2001). The cities that are already over crowded with the growing population in urban areas with all aspects of the lives--will continuously cause the city to no longer be able to accommodate population activities. The area of the city is administratively limited so that it must look at the surrounding peripheral area as an overflow area for urban development activities.

As an impact of the development of the city, there is a tendency to shift urban functions to the outskirts of the city called urban physical appearance towards the outside. The next consequence is that the suburban will undergo a transformation process both in terms of economic and social aspects.

The special of Yogyakarta (Daerah Istimewa Yogyakarta or DIY) is a unique province in a demographic manner. Based on the results of the Indonesian population projection calculation of 2010-2035, the total DIY population was recorded at 3.72 million people in 2016 (Central Bureau of Statistics of DIY, 2017). Mean while, in 2015 , the total population was 3.67 million people with a population growth rate by $1.13 \%$.

Table 1. Population Number and Growth Rate in DIY (2014-2016)

\begin{tabular}{lrrrrc}
\hline \multirow{2}{*}{ Regency } & \multicolumn{2}{c}{ Number of Population (People) } & \multicolumn{2}{c}{ Growth Rate (\%) } \\
\cline { 2 - 6 } & \multicolumn{1}{c}{2014} & \multicolumn{1}{c}{2015} & \multicolumn{1}{c}{ (2016 } & $2014-2015$ & $2015-2016$ \\
\hline Kulon Progo & 407,709 & 412,198 & 416,683 & 1.10 & 1.09 \\
Bantul & 959,445 & 971,551 & 983,527 & 1.26 & 1.24 \\
Gunungkidul & 707,794 & 715,282 & 722,479 & 1.06 & 1.01 \\
Sleman & $1,154,501$ & $1,167,481$ & $1,180,479$ & 1.12 & 1.11 \\
Yogyakarta & 407,667 & 412,704 & 417,744 & 1.24 & 1.22 \\
DIY & $3,637,116$ & $3,679,176$ & $3,720,912$ & 1.16 & 1.13 \\
\hline
\end{tabular}

Source: Central Bureau of Statistics of DIY, 2017

Table 2. Population Density by Regency/City in DIY(2011-2016)

\begin{tabular}{lrrrrrr}
\hline Regency/City & Area $\left(\mathrm{Km}^{2}\right)$ & \multicolumn{5}{c}{ Population Density } \\
\cline { 3 - 7 } & & \multicolumn{1}{c}{2011} & 2012 & 2013 & 2014 & \multicolumn{1}{c}{2015} \\
\hline Kulonprogo & 586.27 & 672 & 680 & 688 & 695 & 703 \\
Bantul & 506.85 & 1,819 & 1,844 & 1,869 & 1,893 & 1,917 \\
Gunungkidul & $1,485.36$ & 461 & 466 & 471 & 477 & 482 \\
Sleman & 574.82 & 1,942 & 1,964 & 1,986 & 2,008 & 2,031 \\
Yogyakarta & 32.50 & 12,077 & 12,234 & 12,390 & 12,544 & 12,699 \\
DIY & $3,185.80$ & 1,102 & 1,115 & 1,128 & 1,142 & 1,155 \\
\hline
\end{tabular}

Source: Central Bureau of Statistics of DIY, 2016

The distribution of DIY residents is centralized in Sleman and Bantul Regency. Both regencies have dispersed population which tends to increase. In proportion, the distribution of the population in Gunungkidul and Kulonprogo Regency is decreasing even though it is increasing in terms of absolute number. This happens because the growth rate is slower compared to Sleman and Bantul Regency. Meanwhile, the city of Yogyakarta became an area with a saturated population and even tends to decrease due to the limited administrative areas for settlements (see Table 1.2). 
The growth in the city of Yogyakarta is driven by various types of trade (especially the retail sector), tourism, and education. It is inevitable that the rapid development of Yogyakarta City has caused a shifting development boundary reaching Sleman Regency and Bantul Regency (agglomeration). The construction of shopping centers, universities, as well as residences increasingly shifts to the suburbs region and even to the outside area of the town. The city of Yogyakarta has grown, developed, and reached the surrounding area which then agglomerates to form Yogyakarta Urban Areas (Kawasan Perkotaan Yogyakarta or KPY) or Greater Yogya. Together with the construction of infrastructure in the form of activity centers connection corridors, KPY becomes the core and point of development in the provincial spatial planning of Special Region of Yogyakarta.

KPY as a form of Yogyakarta City agglomeration reaching Sleman Regency and Bantul Regency is an administrative area that is adjacent to the interdependent regions. When a city is small, built and only covers a small part of the administrative boundary, the management of urban infrastructure and facilities is only a simple issue compared to the complicated management that arises from the development of a city whose area is exceeding the administrative limit.

In between regions, the uneven distribution of resources caused a disparity in the rate of economic growth. This inequality of resources will be reflected in the concentration of economic activities that occur in certain regions. The areas where economic activities are concentrated are called as the agglomeration economies. As stated by Bradley and Gans (1996), agglomeration economy is an externality that results from the geographical proximity of an economic activity. Furthermore, the existence of an agglomeration economy can have a positive influence on the rate of economic growth. As a result, regions that are included in agglomeration generally will have a higher growth rate compared to regions that are not included in agglomeration.

The positive relationship between geographical agglomeration of economic activities and economic growth has been widely proven in some research (e.g. Martin and Octavianno, 2001). Agglomeration produces spatial differences in income levels. The more the economy is agglomerated spatially, the more the growth will increase. The same result was also shown by Ariesy Tri Mauleny (2015) that the agglomeration of production had a positive influence on economic growth.

Based on these facts, it would be interesting to examine how Yogyakarta's agglomeration which is limited by population agglomeration and production agglomeration affects economic growth in DIY. Therefore, the empirical analysis is limited to Yogyakarta as the center of the economy with one city and four regions.

The optimal agglomeration saving theory and city size theory illustrate the spatial equilibrium configuration of economic activity as a result of centripetal and centrifugal forces. The centripetal strength indicated by the agglomeration savings is all economic activities which include the industrial activities and urban areas activities. It is known that centrifugal strength is the dispersion of strength. The development of the city is highly correlated with the development of existing infrastructure and facilities (Kuncoro, 2012: 219).

Montgomery in (Kuncoro, 2012: 222) defines agglomeration as the spatial concentration of economic activity in urban areas as savings due to its economies of proximity. This is associated with the spatial clusters of companies, workers, and consumers. The old perspective believes that agglomeration is a spatial form and is associated with the concept of austerity through the concept of externality to estimate the magnitude of the economic scale. Meanwhile, urban economists define the city as a result of spatial agglomeration production.

The agglomerations that produce clusters will increase the urbanization flows. This is influenced by labor supply on one side. Whereas, the employment opportunities are inadequate and not evenly distributed in all other regions. The concentration of an economic activity particularly in one area will cause the area to experience a development that is much higher than the surrounding areas. If the influence spreads to several cities around it, it will produce a phenomenon that will make the other administrative areas become similar in style and function. If it is processed and planned further, this will result in a bigger city which is a combination of several cities called as megapolitan (Kim, 1999). 
Furthermore, Juoro (1989) conducted a regression of homogeneity level as a function of the agglomeration economy variables : urban population and number of producer services (in this case is the number of financial institutions). The results show that urban population have a positive significant effect on the level of homogeneity. This means that the greater the urban population, the more productive the industry will be located in urban areas. In other words, the urban population is a determinant of the urbanization economies. However, the population squared shows a negative and significant sign. This means that the population no longer has a positive effect on productivity when the number exceeds the optimum limit, but, on the contrary, it has a negative effect (urbanization diseconomies).

Sodik and Dedi (2007) used the data from 26 provinces starting from 1993 to 2003 with the GLS method to estimate the panel data. The dependent variables used in the model is economic growth while the independent variables are agglomeration, labor, inflation rate, trade, and human capital. The results found that regional economic growth from 1993 to 2003 was influenced by labor, inflation rates, and trade. Mean while, human capital and agglomeration did not affect the regional economic growth.

Hasanah (2016) also conducted a study in Central Java Province showing that industrial agglomeration variables did not affect the economic growth of a regency/city in Central Java Province because the level of industrial agglomeration in Central Java Province was still relatively weak. On the other hand, Sandhika, and Mulyo (2012) conducted a study in Kendal Regency with a sub-district analysis unit. The study showed that agglomeration had a positive and significant effect on economic growth.

The measurement of agglomeration can be done in several ways including the use of population proportion and production proportion. Widarjono (1999) used a population proportion and found that there is a causal relationship between population growth and economic growth. Meanwhile, Suryaningrum (2000) stated that agglomeration is the proportion of urban population (urban area) to the population in the province.

\section{METHOD}

The object of this study is the Special Region of Yogyakarta (Daerah Istimewa Yogyakarta or DIY).The approach used is a quantitative descriptive method with panel data The data used are all cities and regencies in from 2005-2016. The secondary data were obtained from the results of second party processed data (external data).The data used are GRDP on the basis of constant prices in 2000, population number, labor force, unemployment, poverty, and HDI (Human Development Index) from 2005 to 2016.

Based on the previous research, the analysis in this research is done by using two indicators. The first one is production agglomeration and the second one is population agglomeration. By using these two models of economic growth, two stages will be carried out. In the first stage, there are population agglomeration and production agglomeration. In the next stage, there are labor force, unemployment, poverty, and HDI.

The model used in this study can be written as follows:

$$
Y_{i t}=\alpha+\beta_{1} x_{i t}+\varepsilon_{i t}
$$

$Y_{i t}$ is the dependent variables used namely Economic Growth, $X_{i t}$ is the determining factor of those three indicators. $\alpha_{i t}$ is an individual effect that is constant between time-t and specific for each cross-section $\mathrm{i}$-unit. $\mathrm{i}=1,2, \ldots, \mathrm{n}$ refers to the cross-section unit, and $\mathrm{t}=1,2, \ldots, \mathrm{t}$ refers to a certain time. The ordinary least square method can provide consistent and efficient estimates of $\alpha$ and $\beta$. On the other hand, the determinant indicator $X_{i t}$ consists of agglomeration (production and population), labor force, the unemployment rate in the regency/city DIY.

$$
\text { Model I, PE1 } 1_{i t}=\alpha_{i t}+\beta_{1} A g l P D R B_{i t}+\beta_{2} A g l P D D K_{i t}+\varepsilon_{i t} g
$$


Model II, PE $2_{\text {it }}$

$$
\begin{aligned}
& =\alpha_{i t}+\beta_{1} A_{g l P D R B_{i t}}+\beta_{2} \text { AglPDDK }_{i t} \\
& +\beta_{3} A K_{i t}+\beta_{4} T P G G_{i t}+\beta_{5} T_{M K N}+\beta_{6} I P M_{i t}+\varepsilon_{i t}
\end{aligned}
$$

Where

T : time (2005-2016)

I : regency/city (5 regions)

PE : economic growth (\%)

AgIPDRB : production agglomeration is a comparison of sub-region/regional GRDPwith provincial GRDP (\%)

AgIPDDK : population agglomeration is a comparison of sub-region/regional population with a provincial population (\%)

AK : Workforce (\%)

TPGG : unemployment rate (\%)

TMKN : poverty level (\%)

IPM : Human development indeks (\%)

Theoretically, there are several benefits obtained from the use of those combined data. First, there are a number of observations for the population parameter estimations that have a positive impact on the degree of freedom and reduce the potential of collinearity between independent variables. Second, it is possible to estimate each individual characteristic in a separate time. Thus, the analysis of estimation results will be more comprehensive and include things that are closer to reality (Hsiao, $2014: 5$ ).

In the data panel regression model estimation technique, there are three techniques that can be used such as Pooled Least Square (common), Fixed Effects, and Random Effects model. To choose which technique to use in the data panel regression, there are three tests to determine the most appropriate technique for the data panel regression estimation, namely: $\mathrm{F}$ statistical test is used to choose either Pooled Least Square (common) or Fixed Effect technique. Then, Langrange Multiplier (LM) test is used to choose between PLS (common) technique or Random Effect technique. Last but not least, to choose between the Fixed Effect or Random Effect technique, Hausmann test is used (Widarjono, 2009 : 255)

Chow Test or some books call it anF Statistics test is a test to choose whether the model used is Pooled Least Square (common) or Fixed Effect. The assumption that each cross-section unit has the same behavior tends to be unrealistic due to the possibility that each cross-section unit might have a different behavior. The F statistics test can be seen as follows (Green, 2000: 562)

$$
F=\frac{\left(R_{u}^{2}-R_{p}^{2}\right) / n-1}{\left(1-R_{u}^{2}\right) / n T-n-k}
$$

$\mathrm{R}^{2}$ is the coefficient of determination, $\mathrm{u}$ refers to unrestricted model and $\mathrm{p}$ refers to pooled or restricted model, $\mathrm{n}$ is the number of cross-section units; $\mathrm{T}$ is the time unit, and $\mathrm{k}$ is the number of parameters to be estimated (Green, $2000: 562$ ). If the results of test calculation are $F \geq F[(n-1)$, (nT$\mathrm{nk})], \mathrm{H}_{0}$ is rejected which means that the intercepts for all cross section units are not the same. In this case, the fixed effect model will be used to estimate the regression equation.

In the panel regression, the different models such as one-way or two-way error correction models (ECM) can be formed by taking the error-term structure in to account. In the one-way error component regression model, there is only one effect that is the individual effect or time effect. Whereas, in the two-way error component regression model, there will be both effects of individual effect and time effect. In the one-way error component model, $\mu_{i}$ is denoted as a specific individual 
un observable effect, whereas $v_{i t}$ is a disturbance $\left(\left(u_{i t}=\mu_{i}+v_{i t}\right)\right.$.On the other hand, in the regression two-way error component model, $\mu_{i}$ is interpreted as an unobservable specific individual effect with $\lambda_{t}$ as the unobservable time effect and $v_{i t}$ as the stochastic disturbance term. Furthermore, to determine which model is the most suitable, the individual existence and/or time effect must be tested. In this test, the null hypothesis test is as follows:

$$
\begin{array}{ll}
\text { Hol }: \sigma_{\mu}^{2}=\sigma_{\lambda}^{2}=0 & \text { (no time and individual effects) } \\
H o 2: \sigma_{\mu}^{2}=0 & \text { (no individual effects) }
\end{array}
$$

The test of the two null hypotheses above can be done by F-test or Haussmann-test. In this study, the hypothesis test to determine whether there is a component of time or individual effect will be carried out through the Haussmann-test (Baltagi, 2005 : 66)

Fixed Effects significance test or called as Chow test is used to determine the best model between the common effects model and the fixed effects model. If $\mathrm{F}$ statistic $>\mathrm{F}$ table or if the $\mathrm{F}$ statistic probability value is $<0.05(\alpha=5 \%), \mathrm{H}_{0}$ will be rejected which means that Fixed Effect model is better than the Common Effect model. If the $\mathrm{F}$ statistic $<\mathrm{F}$ table or if the F-statistic probability value is $>0.05(\alpha=5 \%), H_{0}$ will also be rejected which means that the Common Effect model is better than the Fixed Effect model.

Table 3. Chow Test (Fixed Effects Significance Test) of PE

\begin{tabular}{llccc}
\hline \multicolumn{1}{c}{ Model } & Effect Test & Statistic & d.f & Prob \\
& & & & \\
\hline PE I Equation & Cross-section F & 1.768576 & $(4,51)$ & 0.0096 \\
PE II Equation & Cross-section F & 18.554422 & $(4,47)$ & 0.0000 \\
\hline \multicolumn{5}{c}{ Source: Processed } \\
\hline
\end{tabular}

Based on Table3, the PE equation has an F-statistic probability value of $<0.05$ so that it is significant and $\mathrm{H}_{0}$ is rejected. This means that the Fixed Effect model is better than the common effect.

Table 4. Hausmann Test of PE

\begin{tabular}{cccc}
\hline Model & $\chi 2$ Count & df & Prob \\
\hline PEI Equation & 6.951600 & 2 & 0.0309 \\
\hline
\end{tabular}

Source: Processed Data

Based on Table 4, the results for Hausmann test on PE I equation showed that the chi-square probability is 0.0309 . This is smaller than 0.05 so that $\mathrm{H}_{0}$ is rejected. Thus, the estimation shows that the fixed effect approach is better than the random effect approach. It can be said that there are differences between units that can be seen through differences inconstant term. In fixed effects, the model assumes that there is no time-specific effect and only focuses on individual-specific effect.

Nevertheless, the Hausmann test for PE II equation is not performed because the random model cannot be done so that the fixed effects model is used with GLS estimation.

\begin{tabular}{|c|c|c|}
\hline Variable & PE I Equation & PE II Equation \\
\hline Kontanta & 2000.650 & 1893.010 \\
\hline AGLPDRB & 0.299467 & $0.648074 * * *$ \\
\hline AGLPDDK & $0.400870 * * *$ & $-0.014534 * * *$ \\
\hline LOGAK & & $-0.639843 * * *$ \\
\hline LOGPGG & & $-29.58356 * * *$ \\
\hline
\end{tabular}

Table 5. Estimation Results of Fixed Effect GLS Equation Model for Dependent PE Variables 


\begin{tabular}{lcc}
\hline TMKN & & $-4.773170^{* * *}$ \\
IPM & & $0.976671^{* * *}$ \\
R2 & 0.171387 & 0.905727 \\
Adj R2 & 0.073903 & 0.885669 \\
Fixed Effects & Fixed Effects & Fixed Effects \\
JOGJA & -3.365143 & -6.635019 \\
SLEMAN & -3.818873 & -3.625134 \\
BANTUL & -0.217163 & 0.101950 \\
GUNUNGKIDUL & 2.021190 & 2.948102 \\
KULONPROGO & 4.819132 & 6.104265 \\
\hline
\end{tabular}

*** $\operatorname{sig}$ on $\alpha=0,01 ; * * \operatorname{sig}$ on $\alpha=0,05 ;{ }^{*} \operatorname{sig}$ on $\alpha=0,10$

Source: Processed Data

\section{RESULT AND DISCUSSION}

Based on the estimation results of the regime Fixed Effects agglomeration has no effect in model I but has a significant effect on economic growth in model II. This shows that the economic growth in DIY is influenced by the production agglomeration (the other variables that affect the economic growth variables are included in the model).

The population agglomeration has a significant effect on DIY economic growth in the equation I and equation II but in a negative direction. This means that the rising population growth will reduce economic growth. The negative impact of population agglomeration on economic growth is in accordance with the study of Thomas R. Malthus (1766-1834) in Widarjono (1999:149-150) about the negative effects of population growth and economic growth explained in a book he wrote entitled An Essay on the Principle of Population. High population growth will reduce per capita output. If there is population growth without an increase in other inputs such as capital and the diminishing return, the law will reduce output growth. Despite other increases in input, rapid population growth will continue to reduce per capita output growth.

The results obtained are in accordance with the New Economic Geography hypothesis and theory. The existence of industrial concentration can increase productivity derived from increasing returns, cheap transportation costs, and migration which ultimately have a positive impact on economic growth in the region. A positive relationship between the agglomeration of economic activities and economic growth has been widely demonstrated (Martin and Octavianno, 2001).

Agglomeration produces spatial differences in income levels. If an economy is more agglomerated spatially, it will increase its growth. The areas which have many manufacturing industries grow faster than regions that have few manufacturing industries. This is due to the fact that regions with more processing industries have capital accumulation. In other words, regions with are concentrated on manufacturing industries are growing faster than regions that have no concentration on manufacturing industries.

As explained by Otsuka (2006) in concern with the influence of industrial agglomeration on economic growth in Japan, it is known that the manufacturing industry agglomeration caused by localization gave an increase in productivity by 0.13 percent for every 1 percent increase in the level of localization economies. Localization economies caused by manufacturing industry agglomeration also has an impact on convergent growth.

Labor force has a significant effect on the economic growth of DIY in a negative direction in the equation II. This indicates that more labor force will cause the DIY economic growth to decrease. The labor force is the total number of people who have worked along with people who are already working before (total work force) thus affecting the economic growth in the province in opposite direction.

In relation to labor force that negatively affect economic growth, the need to improve workers' skills can be done through formal and non-formal education. Increased knowledge and expertise will 
encourage the work productivity. Companies will get more output by employing workers who have high productivity so that the company will be willing to provide higher wages/salaries to these workers. In the end, someone who has high productivity will get better welfare which can be shown through the increased income and consumption. There for, a high level of education can increase economic growth.

Number of unemployment has a significant impact on DIY economic growth in a negative direction. In other words, a higher number of unemployment will reduce DIY economic growth. The research is supported by the theory conveyed by Murni (2006: 202), namely that rising unemployment can make economic growth decline because people's purchasing power falls, resulting in a lethargy for entrepreneurs to invest. Based on this opinion that there is an influence between unemployment with economic growth.

Poverty level significantly affects DIY economic growth in a negative direction. It points out that the higher the poverty level, the lower the economic growth. This shows that poverty is a major problem that must be handled seriously so that the level of poverty must be reduced. Poverty boils down to the vicious circle of poverty theory. This theory was discovered by Ragnar Nurkse, who said: "a poor country is poor because it is poor" (a poor country is poor because it is poor). Underdevelopment, market imperfections, and lack of capital cause low productivity. Low productivity results in low income received. Low income will have implications for low savings and investment. Low investment results in underdevelopment, and so on. So it can be said that poverty will reduce economic growth through low income which has implications for low savings and investment (Kuncoro, 2014: 246).

Human development index significantly influences the economic growth of DIY in a positive direction. It can be said that higher human development index will increase DIY economic growth. According to Feriyanto (2014) the human development index is a measure of human development achievements based on a number of basic components of quality of life.

The human development index is a concept that underlies development to achieve human welfare as the ultimate goal of development. Efforts to prosper the community in human development include three basic components, namely life expectancy (health), adult population literacy and school average (education) and purchasing power (income) (BPS, 2008).

This dimension of development is broader than just forming professional and skilled people so that it is useful in the production process. Human income as the subject of development emphasizes the importance of human empowerment, namely the ability of humans to actualize all their potential. The formation of human capital is the process of obtaining and increasing the number of people who have the expertise, education and experience that is decisive for the economic and political development of a country (Korten, in Kuncoro, 2006 : 118).

\section{CONCLUSION}

The economic growth of the Special Region of Yogyakarta (Daerah Istimewa Yogyakarta or DIY) surrounding areas is naturally originated from agglomeration which was driven by the spatial concentration of economic activities including the aspects of space, community level, city scale, and region. The influence of agglomeration for economic growth represented by the equation model of economic growth in Yogyakarta can be measured through the variables of production agglomeration and population agglomeration. The regression results show that both production and population agglomeration have a significant influence on the economic growth of Yogyakarta. This phenomenon occurs because the agglomeration of economic and population activities in the city of Jogja which tends towards the north (read: Sleman district) has led to an increase in the development gap between regencies / cities in DIY (Kuncoro, 2006).

The value of fixed effect cross in the test which only involves the production and population agglomeration variables show that the largest positive influence in economic growth is given by 
Kulonprogo and Gunungkidul respectively. Meanwhile, Bantul, Sleman, and Jogya City actually show a negative influence. Thus, the development policy for Kulonprogo, Gunungkidul, Bantul, Sleman, and Jogya City must be carried out with a different approach. The government should prioritize development policies for Kulonprogo and Gunungkidul through the increased production because those two regencies significantly increase economic growth.

The government needs to prioritize the productivity improvement and added value of the sectors through local resources strengthening such as marine, fisheries, agriculture, as well as trading and services, especially for Kulonprogo Regency. The establishment of an integrated urban area of Yogyakarta Urban Agglomeration (Aglomerasi Perkotaan Yogyakarta or APY)is a strategic step for the synergy of inter-city and regency in the formation of regions that are better in terms of planning, urban planning, and solutions to various problems in Yogyakarta and its surroundings such as puddles, congestion, and water management. In addition, this effort is also at once reduce the impact of other negative externalities that occur as excesses of urban development.

The development agglomeration process that results in the increasing disparity between ruralurban and poor-rich population is a problem that must be resolved. This problem can be eliminated slowly by reviewing the development strategy with all public policies and social policies. Short-term solutions can be done through the distribution of investment and technology transfer in underdeveloped regions so that they can catch up with the current development. Thus, the concentration of the population in an area can be avoided and economic activities triggered by an increase in demand can be increased.

The government should pay attention to the aspects of human resources development. Human resources are an important variable and proven to increase economic growth and create an economic activity concentration. There needs to be a repositioning of education policy in Indonesia considering that education is an investment. The consequence of repositioning is that it is necessary to establish and disseminate the minimum education service standards in various types and levels of education including the aspects of equity, efficiency, participation, quality, and sustainability.

\section{REFERENCES}

Ariesy Tri Mauleny, 2015, Jurnal Ekonomi dan Kebijakan Publik, Vol. 6. No. 2, 147-162 Pusat Penelitian, Badan Keahlian DPR RI

Baltagi, B. H. 2005, "Econometric Analysis of Panel Data", Third Edition, John Wiley \& Sons, LTD, The Atrium, Southerm Gate, Chichester West Sussex P0198SQ, England

Bradley, Rebecca \& Gans, Joshua S. 1996. Growth in Australian Cities, the Economic Record, the Economic Society of Australia, Vol. 74. No. 226, 1-25.

Feriyanto. N 2014. Ekonomi Sumber Daya Manusia dalam Perspektif Indonesia. Yogyakarta: UPP STIM YPKN

Green,W. 2000, "Econometric Analysis", Fourt Edition, New Jersey-USA.

Gudjarati, D. N. 1995. Basic Econometric, $3^{\text {rd }}$ edition, Mc. Graw Hill, Singapore.

Hasanah, F. 2016, "Analisis Pengaruh Aglomerasi Industri, Angkatan Kerja dan Human Capital Investment Terhadap Pertumbuhan Ekonomi Kabupaten/Kota di Propinsi Jawa Tengah Tahun 2012-2014", Jurnal Pendidikan dan Ekonomi, Vol. 5. No. 4, 283-291

Hsiao C. 2014. Analysis of Panel Data, Cambridge University Press, Third Edition, Cambridge University Press.

Juoro, U, 1989. Perkembangan Studi Ekonomi Aglomerasi dan Implikasi Bagi Perkembangan Perkotaan di Indonesia, Jurnal Ekonomi dan Keuangan Indonesia, Vol. 37, No. 2, 269-294

Kim, S. R. 1999, Resources, and Economic Geography: Source of US. Regional Comparative Advantage, 1880-1987, Journal Regional Science and Urban Economics, 29, 1-32

Kuncoro, M. 2002. Analisis Spasial dan Regional, Studi Aglomerasi dan Kluster Industri Indonesia., UPP AMP YKPN. Yogyakarta. 
Kuncoro, M. 2006. Ekonomi Pembngunan Teori, Masalah dan Kebijakan. Edisi Keempat. UPP STIM YKPN. Yogyakarta

Kuncoro, M. 2014, "Otonomi Daerah : Menuju Era Baru Pembangunan Daerah", Jakarta: Penerbit Erlangga, Edisi. 3

Malecki. 1991. Technology and Economic Development: the Dynamics of Local, Regional, and National Change. New York: John Wiley \& Sonc, Inc.

Martin P. and Ottavianno. 2001. Growth and Agglomeration, International Economic Review, Vol. 42, No. 4, 947-968

McGee T.G. 1991. The Emergence of Desakota Regions in Asia. Expanding a Hypothesis. Honolulu: University of Hawai Press.

Riyadi, R. 2001, "Dinamika Spasial Wilayah Perkotaan (Kasus Daerah Kabupaten Sleman DIY)" dalam Dimensi Keruangan Kota, Teori dan Kasus, Penerbit Universitas Indonesia, UI-Press

Sandhika, A,W. dan Mulyo, H. 2012, "Analisis Aglomerasi, Tenaga Kerja, Jumlah Penduduk, dan Modal Terhadap Pertumbuhan Ekonomi Kabupaten Kendal", Diponegoro Journal Economics, Vol. 1, No. $1,1-6$

Sodik, J. dan Dedi, I. 2007, "Aglomerasi dan Pertumbuhan Ekonomi : Peran Karateristik Regional di Indonesia", Jurnal Ekonomi dan Studi Pembangunan, Fakultas Ekonomi UMY, Yogyakarta, Vol. 8, No. 2,: $117-129$

Suryaningrum, A. 2000, "Pertumbuhan Ekonomi Regional", Media Ekonomi dan Bisnis, Undip, Semarang, Vol. 12, No. 1, 8-16

Widarjono, A. 1999, "Analisis Kausalitas Penduduk dan Pertumbuhan Ekonomi di Indonesia", Jurnal Ekonomi Pembangunan, Vol. 4, No. 2, 24-30

Widarjono, A. 2009, "Ekonometrika Teori dan Aplikasi untuk Ekonomi dan Bisnis", Edisi Kedua, Ekonesia Fakultas Ekonomi UII, Yogyakarta , Statistik Indonesia, BPS, Several editions 